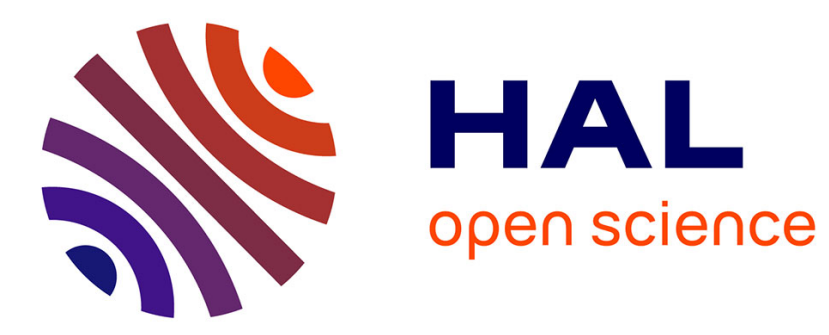

\title{
A Nation That Dares Not Speak Its Name? \\ David Mccrone
}

\section{To cite this version:}

David Mccrone. A Nation That Dares Not Speak Its Name?. Ethnicities, 2006, 6 (2), pp.267-278. 10.1177/1468796806063757 . hal-00571861

\section{HAL Id: hal-00571861 https://hal.science/hal-00571861}

Submitted on 1 Mar 2011

HAL is a multi-disciplinary open access archive for the deposit and dissemination of scientific research documents, whether they are published or not. The documents may come from teaching and research institutions in France or abroad, or from public or private research centers.
L'archive ouverte pluridisciplinaire HAL, est destinée au dépôt et à la diffusion de documents scientifiques de niveau recherche, publiés ou non, émanant des établissements d'enseignement et de recherche français ou étrangers, des laboratoires publics ou privés. 
Copyright $\odot 2006$ SAGE Publications (London, Thousand Oaks, CA and New Delhi) 1468-7968 Vol 6(2):267-278;063757

DOI:10.1177/1468796806063757

http://etn.sagepub.com

\section{A nation that dares not speak its name?}

The English question

\section{DAVID MCCRONE ${ }^{1}$}

University of Edinburgh

R. Colls, Identity of England. Oxford: Oxford University Press, 2002. 409 pp. ISBN 0-199-24519-3, pbk.

K. Kumar, The Making of English National Identity. Cambridge: Cambridge University Press, 2003. 367 pp. ISBN 0-521-77736-4, pbk.

R. Weight, Patriots: National Identity in Britain, 1940-2000. London: Macmillan, 2002. 866 pp. ISBN 0-330-49141-5, pbk.

Never has there been such interest in the English question as there is today. It is easy to lose count of the number of scholarly as well as journalistic books that have been published in the last decade on what it means to be English and/or British in modern times. In popular vein, there are The English Tribe (1996) by Haseler, The English: Portrait of a People (1999) by Paxman, Nor Shall my Sword: The Reinvention of England (2000) by Heffer, Scruton's England: An Elegy (2000), and Patriots: National Identity in Britain, 1940-2000 by Weight (2002). The latter, together with the more scholarly works by Colls, The Identity of England (2002), and Kumar, The Making of English Identity (2003), provide the main focus for this review article.

The first thing to be said in this review is that these books are but the latest in a genre of writing about life and identity in these islands. Robert Colls, for example, together with Philip Dodd, wrote Englishness, in 1985, and Newman's The Rise of English Nationalism was published a year later. The popular vogue for historical writing has also led to useful works such as Samuel's Patriotism: The Making and Unmaking of British National Identity (1989), Kearney's The British Isles: A History of Four Nations (1989), more recently, Norman Davies's The Isles (1999), and Simon Schama's book of the television series A History of Britain (3 volumes) 
published between 2000 and 2003. What most of these have in common is a willingness to problematize 'Britain'. In truth, one can trace this to a seminal article in the Journal of British History by a New Zealander, John Pocock, in 1975 entitled 'British History: a plea for a new subject' (perhaps it took a 'foreigner' to point that out). Pocock's point was that hitherto what one got was mainly English history (the Scots, the Irish and the Welsh had their own sub-disciplines), and rarely a genuine and interactive history of the four nations of these islands and how they related to each other. This genre of writing was given a fillip by Linda Colley's influential book, Britons: forging the nation, 1707-1837, published in 1992.

It is interesting and significant that these are mainly 'history' books, although the stimulus for much of this is essentially the political, social and cultural issues of today. In this short review, my argument is as follows: that problematizing 'Britain' is the result of three sets of challenges that pushed through to the surface of life in these islands, although their roots go much deeper. These challenges are (in no particular order of importance): the constitutional anomaly of the British state; growing racial and ethnic diversity; and the issue of Europe. The first of these is conventionally expressed as the rise of 'nationalism' in Scotland and Wales, a feature of the last 25 years, but in truth embedded in the curious anomaly that since 1707 there has been a single British parliament, that the UK was a unitary rather than federal state despite the fact that it contained four territories - England, Scotland, Wales and (since 1921) Northern Ireland. The attempt to resolve the constitutional anomaly culminated in the setting up of devolved governments in the non-English territories in 1999. The second challenge to Britain, but especially to England where most settled, was growing ethnic diversity following the immigration of people from the black and brown Commonwealth in the post-war years. If the first challenge generated a literature on multinationalism and constitutional change, the second created one on multiculturalism and ethnic relations, literatures which, by and large, did not touch each other. The final challenge to what it meant to be British (but above all, English) came from Europe, or more precisely, the UK's entry into the European Economic Community (EEC) in 1973. All three challenges have generated something of an explosion in writing, both scholarly and popular. Sometimes, key books span the divide, such as Tom Nairn's The Break-Up of Britain, in 1977, and Paul Gilroy's There Ain't No Black in the Union Jack, in 1987. What has also helped this debate along is its politicization, namely, the mobilization of political parties around these challenges. Sometimes, all three intersect, notably on the right of the political spectrum, where issues of 'nationalism'/devolution, race and ethnicity, and 'Europe' become the dominant motifs of the Conservative right - they are 'against' all three. Little wonder, then, that one finds a rich vein of writing (and broadcasting) stretching from reactionary rants through to popular histories and scholarly treatises. 
Much of this work focuses down on what it means to be English. England is something of an 'unimagined community' (1996). ${ }^{2}$ This needs a bit of explanation. Why not 'British'? In truth, it often is, but my argument is that the core-people of these islands - residents of England are 85 percent of the UK population - are at the sharp end of this identity crisis. The Scots, and to a large degree, the Welsh, have less of a dilemma. Usually, they treat being British as something of a supranational, a state, identity. They are Scots or Welsh in terms of their 'nationness', their nationality if one prefers, and British in terms of citizenship. For the English it is not so simple. In a previous article in this journal (McCrone, 2002), I explored these identity conundrums, and quoted this observation from the journalist Anthony Barnett:

What is the difference between being English and being British? If you ask a Scot or a Welsh person about their Britishness, the question makes sense to them. They might say that they feel Scots first and British second. Or that they enjoy a dual identity as Welsh-British, with both parts being equal. Or they might say. 'I'm definitely British first'. What they have in common is an understanding that there is a space between their nation and Britain, and they can assess the relationship between the two. The English, however, are more often baffled when asked how they relate their Englishness and Britishness to each other. They often fail to understand how the two can be contrasted at all. It seems like one of those puzzles that others can undo but you can't; Englishness and Britishness seem inseparable. They might prefer to be called one thing rather than the other - and today young people increasingly prefer English to British - but, like two sides of a coin, neither term has an independent existence from the other. (Barnett, 1997: 292-3)

A few years, and a large research programme ${ }^{3}$ on, I am not so sure. Certainly, the account carries for the Scots and the Welsh. Asking people to relate their Scottishness and Welshness to their Britishness is usually construed as asking them to relate national to state identity, and to be sure, there has been a firming up of the former over the latter, though it is by no means the case that they have ceased to call themselves British. The English, on the other hand, seem more likely than before to use the descriptor 'English', especially with regard to sport (witness the outbreak of English flags during recent football tournaments), to landscape, history and heritage. Matters of politics, governance and social affairs, including 'race' relations, are, by and large, deemed to be 'British' ones. Put more sharply, it seems that there are different agendas in the different territories of the UK. The most obvious difference is the one (or ones, rather) in Northern Ireland, where being 'British' is most clearly a trigger for one's political and cultural affiliations. If you call yourself British, then much of your identity can be construed from that. In Scotland, it is a lot more complex and unpredictable. Put simply, claiming to be 'British' can be a reference to a multiplicity of allusions: having a British passport, a fact of constitutional life, a 
statement of political Unionism, a claim to a liberal, and multicultural, civic identity, or even a synonym for English (Kiely et al., 2005). In Wales, it is probably much the same, with the added nuance that the Welsh can claim to be historically the true Brits who retreated from the invading Angles and Saxons in the 4th-century AD behind Offa's dyke. Most commonly, the Scots, Welsh and Irish are lumped together as 'Celts' (Coll gives us a whole chapter in his book), but this is a term of dubious value, whether in its strong - racial - sense, or its weak - cultural - one, as if the rise of nationalism in these territories is the outcome of inherent, genetic differences, rather than a reaction to politico-cultural processes. ${ }^{4}$

The real dilemma, however, lies with the English. If Barnett is correct, they tend to confuse English and British, because they are in demographic terms the core-people of these islands. Others argue that there is a Pandora's Box conundrum for the English. Bernard Crick argued in his book National Identities: the constitution of the United Kingdom (1991) that if the English asserted that they were English rather than British, the game was up, that one couldn't hold the UK together if only a minority thought they were British. In other words, he argued, the English submerged their national identity to hold the British state together. A more political and contemporary variant of this argument holds that Englishness is actually socially and politically dangerous. The then British Home Secretary, Jack Straw, observed in a radio programme: 'The English are potentially very aggressive, very violent and of course we have used that propensity to subjugate Ireland, Wales and Scotland and then we used it in Europe and without Empire' (Kumar, 2003: 255). This is surely a highly dubious statement to make on a number of grounds: it implies an almost inherent, genetic propensity, and it is also very dubious history. If one were to substitute 'the Germans' or 'the French' or 'the Americans' then there would have been an outcry of some magnitude. While it may give some nationalists in Ireland, Scotland and Wales some comfort to think of their countries as 'internal colonies' of England, this is something of a discredited notion in terms of evidence (McCrone, 1992).

Leaving aside dubious notions of 'innate aggression', what are the key questions that distil around notions of nationality and identity in these islands? The first question one might ask is whether there is a confusion of British and English, and if so, why, and with what effect. We might also ask: when did Englishness arise in popular form, assuming that, following Colley, one identifies the emergence of Britishness around Protestantism and warfare from the 18th-century? Finally, if, over time, fewer people choose to call themselves British, will the British state continue? We might in this review interrogate the three main books with a view to seeing how well or badly they tackle these issues.

Of the three, Richard Weight's Patriots: National Identity in Britain, 1940-2000, is the most weighty (an excusably bad pun) only in the sense 
that it runs to well over 800 pages. Throughout, he is aware that Britain does not equal England, but it is perhaps the least satisfactory of the three books. Part of the problem is his tendency to rush in where angels (Angles?) fear to tread. Thus, in his introduction, he asserts that after Scotland's wars of independence in the 14th-century, it was only nominally independent from England; that British national identity was largely a Scottish creation; and repeats the calumny that the kilt was invented by an Englishman. ${ }^{5} \mathrm{He}$ is not exactly comfortable with social science concepts; witness this extraordinary comment: 'The most fashionable theory in social science is Benedict Anderson's idea of 'imagined communities'. This is a subtle reworking of the Marxist idea that nationalism is an ideology developed by capitalists to distract the working classes in the world from their revolutionary date with destiny' (p. 16). What he has written, however, is a fairly orthodox and largely descriptive history of Britain in the second half of the 20th-century. Throughout, he tries to remind himself that Britain is more than England, and absolves himself by saying that the reader would find it too tedious if he made the distinction all the time. This is odd, given that the whole point of the book is exactly that, to write an account of the interweaving of national identities.

The thesis of Weight's book is spelled out at the outset: 'This is a book about why the people of Britain stopped thinking of themselves as British and began to see themselves as Scots, Welsh and English who happened to belong to a state called Britain ...' (p. 1). The implications are: that they have indeed stopped thinking of themselves as British; that they have only begun to consider themselves Scottish, Welsh and English; and that the British state is something of an accident - all highly dubious contentions, and not at all supported by academic research. The book runs through the gamut of 50 years of 20th-century history: the Second World War, the peace and the welfare state, the 1960s and cultural change, Mrs Thatcher and her aftermath. It is structured around 11 chronological characterizations, starting in the 1940s and ending in 2000: warriors, citizens, viewers, shoppers, swingers, nationalists, sceptics, strikers, hustlers, tunnellers, and modernizers. All in all, it is a fairly useful example of the genre: descriptive modern history with a focus on the cultural and political. The trouble, however, lies with the genre itself: how can one simply describe in the expectation that this alone will explain such complex processes. To be sure, such histories simply cannot ignore or downplay England, and so the book shapes up, conventionally, as England-plus. The non-English get walk-on parts as and when they are deemed to matter to the core. To be sure, Weight is by no means alone in this. Simon Schama's (2000-02) three-volume account only wheels on the Scots, Irish and Welsh when they impact on England. In other words, there can be no show without the English Punch. Weight is fairly optimistic about the British future, judging that it has a lot of mileage in it yet. If nothing else, 'The four nations will maintain a contemporary bond 
through culture and trade, both of which are oiled by a common language' (p. 734). Divorce, as such, seems out of the question, and yet the core of his argument is that seamless Anglo-British identity is effectively redundant.

Robert Colls sets himself a more manageable task: to give an account of the English, rather than of their history. It is, he says, 'a history of who they were, written from the perspective of the twenty first century', but above all, 'how the English have thought about themselves' (p. 2). The book belongs in the vein of cultural histories, less concerned with chronology and more with the underlying values and ideas of the English, and how they have thought about themselves. The difficulty with that is that they do not articulate what they think about themselves, and so the author has to interpret the runes for us. This is difficult, because there is not a great deal to go on. The non-English get their familiar walk-on roles in the saga, lumped together in this case into a chapter on 'the Celts'. Colls struggles both to distinguish England from Britain, and to incorporate the non-English into his conception of Britain. This, in large part, is 'England-plus' history. At the same time, one has to read England opaquely, to see it dimly and darkly in the recesses of 'Britain'. The book has two parts. The first deals with English national identity as a political ideology; in other words, how the state (and nation) were constructed from Anglo-Saxon times, and burgeoned as England effectively took over, in his view, Wales, Ireland and Scotland. Of these, Colls argues that while the English relationship with Scotland was key (co-founders of the 1707 Union), that with Ireland was critical (it left the Union in 1921). The bulk of the first part is devoted to examining how the British state developed at home and abroad, the making of political/state identity. In contrast, the second part of the book is concerned with the 'organic' and 'affective' English homeland, the cultural flesh rather than the political shell. This works less well because it is difficult to judge why one should consider some aspects - the English gentleman - more significant than others. The book finds itself in something of a dilemma, which he never quite resolves. In his conclusion, Colls spells it out:

To have talked of an English state would not have done justice to the way political power was shared amongst a British elite. To have talked of a British nation would not have done justice to the actual feelings of the four nationalities who made up that nation. To have talked of four co-equal nationalities would have failed to recognise England's overarching dominance, and too much talk of that would have missed the very real multinational success of Great Britain. So, for over 300 years, the people of these islands have been uncertain. (p. 377)

One might retort that it is the English of these islands who are uncertain, for identity talk is common practice among the Scots, Welsh and Irish, who can talk for Scotland, Wales and Ireland happily and usually at inordinate length. 
Like the cobbler who thought there was nothing quite like leather, it will come as no surprise that the reviewer finds Kumar's sociological account, The Making of English National Identity, by far the most convincing. This is because he is able to bring to bear a conceptual toolkit, as well as his experience as a non-white Brit, to the issue of being English. He comments that an alternative title might have been: 'the enigma of English national identity, that is, why is English national identity seemingly so strange?' Unlike the other two authors, Kumar wishes to locate the modern origins of Englishness in the late 19th-century. This is at odds with the more conventional view, espoused by both Weight and Colls, as well as others, that Englishness owes its origins in the pre-modern period, as early as the 8thor the 13th-century, when 'the people' began to emerge as a significant force in the land, if only to provide tax revenue for the monarch. For example, Adrian Hastings in his attempt to rehabilitate religion as one of the key dimensions of nationalism observes:

Early forms of nationalism related to states already in existence, their defence, glorification or expansion. England ... was the quintessential example of this, but Scotland already in the 14th century provides another example: the wars of liberation to rescue the Scottish state from English dominance produced a recognisable nationalism. In this case, a state preceded the nationalism but the nation may rather have followed it. (1997: 27-8)

One does not have to perform mental gymnastics to accept that modern forms of nationalism, notably associated with the franchise, were of a different order. The point remains that some popular form of national identification is likely to have predated the Union of Scotland and England, if only because it is hard to see just how and why Englishness would have emerged in the late 19th-century, almost 200 years after the emergence of Britishness.

What Kumar is especially good at is locating England and Britain in the exploits of missionary or imperial nationalism. He observes: 'Like many other imperial nations such as the Russians, the Austrians and the Ottomans, the English could not see themselves as just another nation in a world of nations' (p. $\mathrm{x}$ ). This is a highly perceptive comment, because all of those nations have had something of a crise d'identité following the end of Empire. Such was the coterminosity of nation, state and empire that when the latter ended, the core had no readily worked out account of who they were, how they had got there, and where they were going next. In short, failing to have a debate about national identity is not some kind of quaint, forgetful eccentricity, but the result of a structural failure. Claims that it is too dangerous even to mention the subject runs the risk of allowing political extremes to capture the terms of the debate.

The nub of Kumar's argument is that England had something of a mission civilatrice, an imperial quest carried by 'a nationalism that finds its 
principle not so much in equating state and nation as in extending the supposed benefits of a particular nation's rule and civilization to other people' (p. 31). The parallels with France are unmistakable, an irony, given that the capacity of each nation in the last half-century to define itself visà-vis the other. ${ }^{6}$ The role of empire is curiously underplayed in both Weight and Colls, for it helps us understand the attenuated nature of being British, and the ease with which those who did not live in these islands but in far-flung parts of the Empire had aspects to being British - in an echo of Rome, civis Britannicus sum. Indeed, the British imperial exercise involved English, Scots and Welsh equally, and their contribution to Empire cannot be disaggregated into its 'national' components. Being an imperial white gave easier access to being British, but we now know that non-white peoples, black or brown, had different and complex relationships to Britishness, depending on how much or how little cultural capital they were able to accumulate. Ultimately, being British meant having a passport, citizenship, and this helps to explain why non-white people in the UK are much more likely to call themselves British than English (Modood et al., 1997). We may as yet not understand this, whether it is because they do not want to do so, or because they are excluded from so doing. For example, in his television documentary White Tribe (2000), the writer Darcus Howe encountered the senior Conservative politician Norman Tebbit who, when Howe spoke of 'we English', corrected him with the words: 'No, Darcus. We are British, but I am English', implying that the former was a civic identity and the latter an ethnic one. If things are changing, then perhaps they do so slowly.

The propensity of non-white Brits to be 'British' rather than 'English' has led some, such as the journalist Yasmin Alibhai-Brown ('Who do we think we are? Imagining the new Britain', 2001), to express hostility to constitutional change and devolution in Scotland and Wales on the grounds that this might leave Britain in the possession of the English who took an ethnic, and possibly a more reactionary, view of belonging. ${ }^{7}$ Kumar would retort that, in practice, English and British are thoroughly (con)fused, or, rather, 'so interfused as to be indistinguishable' (p. 156), although how he would make sense of the undoubted willingness of people in England to describe themselves as English is not clear. There are a number of possibilities: that the terms English and British are so interchangeable that it is merely a matter of chance, and choice, as to which is used; that popular sentiment, especially associated with sport and football, forefront English over British; that it is some sort of reaction to devolution in these islands such that 'the English question' needs to be resolved. This question is a variant of what came to be known as the West Lothian question, namely, that Scottish MPs at Westminster have a say in domestic English matters such as health and education when they themselves have none in such matters in their own constituencies, which are governed by the Scottish parliament. Finally, being 'English' 
might well be tapping in to a strain of right-wing sentiment which has chauvinistic overtones, both against 'foreigners' and 'Europe', for we know from survey evidence that those who describe themselves as English rather than British have distinctly right-of-centre views on both cultural and social matters (Curtice and Heath, 2000). Thus, the differential between the selfidentified 'unambiguously English' and 'unambiguously British' with regard to attitudes to immigration and ethnic minorities is significant. For example, 70 percent of the former think immigrants take jobs from people born in Britain, compared with 37 percent of the latter (Curtice and Heath, 2000: 168), suggesting that those who choose to describe themselves as English tend to be right-wing.

Kumar accepts that Britishness, at least in its imperial form, has long been in decline, and that traditional notions of Englishness face challenges from three quarters: from revived Scottish, Welsh and Irish nationalism; from immigration and resulting multiculturalism; and from threatened integration into the European Union project. The problem for the English is that they have come belatedly to accept that they are English (as opposed to British), and are, as we speak, still working through the implications of this. Hardly a month goes by without some prominent politician or luminary asking the English question, fumbling towards what the distinction might be between state (British) and national (English) identity. ${ }^{8}$ What makes Kumar's book a much more satisfying account of English identity is that it is informed by social scientific ideas. There is a facility with concepts such as nation, ethnicity and identity that suffuse his narrative account of Englishness such that it has an analytical framework quite lacking in the more descriptive histories of Weight and Colls, who struggle along trying to identify the content of being English. Kumar shows with some elegance that all identities depend upon 'othering', knowing who one is not; that the specific content of identity matters far less than where the boundaries between 'us' and 'them' begin and end. Indeed, there might even be a case for writing a book on being English (or anything else for that matter) in terms of variant 'others', as seen both from inside out, and outside in, as it were. What the French think of the English, and how this is refracted through an acceptance or rejection of such images would possibly make for an insightful account. Be that as it may, there is an argument for social scientists making a much more serious input to public discussions of identities than hitherto. It is gratifying that matters of territorial identity are beginning to be subject to a wide range of discussion and debate, from popular histories and scholarly analyses, as well as political tracts. Identities should be treated as claims made in key social contexts, issues of cultural register as and when these matter. In truth, we have hardly scratched the surface in understanding issues of ethnicity and identity in these islands, and much remains to be done. 


\section{Notes}

1 In writing about England, it seems important to be explicit as to where this reviewer stands. When I go to England from Scotland, I feel I am going to a foreign country. This may seem an odd, even a slightly rude, thing to say: after all, 'foreign' has a somewhat pejorative tone in the English language (interesting in itself). By this I mean that, as a Scot, I find the neighbours perfectly friendly and interesting, and rather reserved. To continue the metaphor, living next door to someone reminds you of what you have in common: shared practices and routines, but not necessarily the intimacies and meanings associated with them. Now and again, you are caught out by assuming there are more shared understandings than are actually there, as if you commit some social faux pas. For example, I recall spending an evening in a Danish pub talking to a prominent English novelist about identity. I mentioned that I could not understand the reticence of English people, unlike the rest of us on the island, to talk about what it meant to be English. The novelist replied testily that it was like asking people about their religion and sex lives, something they were very reluctant to do. The moral of the tale: because you live next door to someone, you can take too much for granted.

2 The allusion is to Benedict Anderson's description of the nation as an 'imagined community' in his book of the same name (1996)

3 Between 1999 and 2004, The Leverhulme Trust funded a major programme of research on Constitutional Change and Identity coordinated at Edinburgh University by the author of this review. See for details http://www.institute-ofgovernance.org/forum/Leverhulme/TOC.html.

4 Even less useful is the term 'Celtic fringe', which betrays one's geopolitical standpoint, rather like centre and periphery. It depends, ultimately, on where you are and how you see the world around you.

5 The right-wing historian Hugh Trevor-Roper made this assertion in his attempt to demolish Scottish nationalism (in Hobsbawm and Ranger, 1984), even though all evidence is to the contrary (Ferguson, 1998).

6 Compare, for example, the mutual and pejorative stereotypes of 'the Frogs' and 'Les Rosbifs'.

7 The evidence from Scotland seems to suggest that non-white people have a greater propensity to use the descriptor 'Scottish', usually in hybrid form such as 'Scottish Muslim'. Why this should be so is not as yet properly understood.

8 See, for example, the debate in the political magazine Prospect (Prospect, 2005), which sets its tone by saying that 'the British have traditionally had a rather weak sense of identity'. One is tempted to ask whether the editor understands the distinction between British and English.

\section{References}

Alibhai-Brown, Y. (2001) Who Do We Think We Are? Imagining the New Britain. London: Allen Lane.

Anderson, Benedict (1996) Imagined Community: Reflections on the Origin and Spread of Nationalism. London: Verso. 
Barnett, A. (1997) This Time: Our Constitutional Reform. London: Vintage.

Colley, L. (1992) Britons: Forging the Nation, 1707-1837. New Haven, CT: Yale University Press.

Crick, B. (1991) National Identities: The Constitution of the United Kingdom. Oxford: Blackwell.

Curtice, J. and Heath, A. (2000) 'Is the English Lion about to Roar? National Identity after Devolution', in R. Jowell, J. Curtice, A. Park, K. Thomson, L. Jarvis, C. Bromley and N. Stratford (eds) British Social Attitudes: The 17th Report: Focusing on Diversity, pp. 155-74. London: Sage.

Davies, N. (1999) The Isles: A History. London: Macmillan.

Dodd, P. and Colls, R. (1985) Englishness: Politics and Culture, 1880-1920. London: Routledge.

Ferguson, W. (1998) The Identity of the Scottish Nation: An Historic Quest. Edinburgh: Edinburgh University Press.

Gilroy, P. (1987) There Ain't No Black in the Union Jack: The Cultural Politics of Race and Nation. London: Hutchinson.

Haseler, S. (1996) The English Tribe: Identity, Nation and Europe. Basingstoke: Macmillan.

Hastings, A. (1997) The Construction of Nationhood: Ethnicity, Religion and Nationalism. Cambridge: Cambridge University Press.

Heffer, S. (2000) Nor Shall my Sword: The Reinvention of England. London: Phoenix.

Hobsbawm, E. and T. Ranger, eds (1984) The Invention of Tradition. Cambridge: Cambridge University Press.

Kearney, H. (1989) The British Isles: A History of Four Nations. Cambridge: Cambridge University Press.

Kiely, R. McCrone, D. and Bechhofer, F. (2005) 'Birth, Blood and Belonging: Identity Claims in Post-devolution Scotland', The Sociological Review 53(1): 150-71.

McCrone, D. (1992) Understanding Scotland: The Sociology of a Stateless Nation. London: Routledge.

McCrone, D. (2002) 'Who Do You Say You Are? Making Sense of National Identities in Modern Britain', Ethnicities 2(3): 301-20.

Modood, T., Berthaud, R., with J. Lakey (1997) Ethnic Minorities in Britain: Diversity and Disadvantage. London: Policy Studies Institute.

Nairn, T. (1977) The Break-Up of Britain. London: New Left Books.

Newman, G. (1987) The Rise of English Nationalism: A Cultural History, 1720-1830. London: Weidenfeld and Nicolson.

Paxman, J. (1999) The English: A Portrait of a People. Harmonsworth: Penguin Books.

Pocock, John (1975) 'British History: A Plea for a New Subject', Journal of British History 47(4): 601-28.

Prospect (2005) 'Rediscovering Britain', Prospect 109 (whole issue) [http://www. prospect-magazine.co.uk/vis_index.php?select_issue=503].

Samuel, R. (1989) Patriotism: The Making and Unmaking of British National Identity. London: Routledge.

Schama, S. (2000-03) A History of Britain (3 vols). London: BBC Books.

Scruton (2000) England: An Elegy. London: Pimlico. 
DAVID MCCRONE is Professor of Sociology and Co-director of the Institute of Governance in the School of Social and Political Studies at the University of Edinburgh. Address: University of Edinburgh, Chisholm House, High School Yards, Edinburgh. EH1 1LZ. [email: D.McCrone@ed.ac.uk] 